\title{
Broad Ligament Papillary Cystadenoma
}

National Cancer Institute

\section{Source}

National Cancer Institute. Broad Ligament Papillary Cystadenoma. NCI Thesaurus. Code C155952.

A cystadenoma that arises from the broad ligament. It is characterized by the presence of small papillary projections in the inner surface of the cysts. It may be sporadic or associated with von Hippel-Lindau disease. 